Part of Journal of Research of the National Bureau of Standards, Volume 19, September 1937

\title{
CALORIMETRIC DETERMINATION OF THE HEATS OF COMBUSTION OF ETHYLENE AND PROPYLENE
}

\author{
By Frederick D. Rossini and John W. Knowlton
}

\begin{abstract}
The data of the present investigation give for the heats evolved in the combustion of gaseous ethylene and propylene in oxygen, at $25^{\circ} \mathrm{C}$ and a constant pressure of 1 atmosphere, to form gaseous carbon dioxide and liquid water, the following values in international kilojoules per mole: ethylene, $1410.97 \pm 0.30$; propylene, $2057.42 \pm 0.62$. Converted to kilocalories by means of the factor $1 / 4.1833$, these values become, respectively, $337.28 \pm 0.07$ and $491.82 \pm 0.15$ kilocalories per mole.

A review of the existing data indicates that the hitherto "best" values for the heats of combustion of these gases differ fron the values obtained in the present investigation by -1.6 percent for ethylene and -0.4 percent for propylene. These differences are, respectively, about 75 and 12 times the estimated uncertainties in the new values.
\end{abstract}

\section{CONTENTS}

I. Introduction

II. Units of energy, molecular weights, etc

III. Method and apparatus

IV. Chemical procedure

1. Preparation and purity of the hydrocarbons......... 252

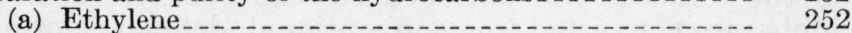

(b) Propylene

2. Purity of the combustion reaction

3. Determination of the amount of reaction

V. Calorimetric procedure

1. Electrical-energy experiments

2. Correction experiments

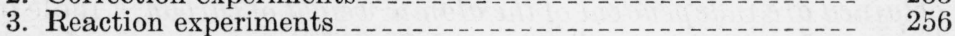

VI. Results of the present investigation _...

VII. Data of previous investigations.

1. Ethylene

2. Propylene

VIII. Conclusion_.

IX. References_......... 261

\section{INTRODUCTION}

Ethylene and propylene are two hydrocarbon gases which have become very important within recent years, because of their availability (of the order of $100,000,000,000$ cubic feet annually) as byproducts from the "cracking" processes of the petroleum industry, and because of their use in the synthesis of alcohols and other chemical substances, as well as of synthetic motor fuels with superior properties. If such processes are to be carried on with an economy of time, energy, and material, it is important that there be accurately known the thermodynamic properties of the reactants and products of these reactions. 
The last determination of the heat of combustion of ethylene was reported in 1901, and that for propylene in 1893. Since those determinations were made, the accuracy of calorimetric measurements has been greatly improved, and it has become possible to obtain these gases in a substantially pure state. Because the old value for the heat of combustion of ethane was found to be in error by about 1 percent [1]," it was suspected that the present "best" values for ethylene and propylene might also be in considerable error. For these reasons, it was desirable that new determinations be made of the heats of combustion of ethylene and propylene.

Furthermore, new values for these gases can be used to deduce reliable values for the heats of combustion and formation of all the gaseous normal olefin (alkene-1) hydrocarbons, by making use of the following: 1, the generalization recently made by Rossini [2] that, in any organic molecule containing a normal alkyl group of more than five carbon atoms, the addition of a $\mathrm{CH}_{2}$ group to the normal alkyl group to form the next higher normal alkyl group results in an increase in the heat of combustion of the organic molecule in the gaseous state, at $25^{\circ} \mathrm{C}$ and a constant pressure of 1 atmosphere, of $157.00 \pm 0.08$ kilocalories per mole; 2 , the data on the heats of combustion of the gaseous normal paraffin hydrocarbons obtained in this laboratory $[1,2]$; and 3 , the data on the heats of hydrogenation of some olefin-1 hydrocarbons recently reported by Kistiakowsky, Vaughan, and their coworkers $[3,4]$.

\section{UNITS OF ENERGY, MOLECULAR WEIGHTS, ETC.}

The unit of energy employed in this work is the international joule, based upon standards of electromotive force and resistance maintained at this Bureau. In order to report the results in calories, as well as in the fundamental unit of electrical energy, values in international joules are converted to a conventional, defined calorie by means of the selected factor $1 / 4.1833$. This is the same factor that is being used in practically all the laboratories in this country and which has been used in previous conversions of values from this laboratory [5].

As in the previous work on the hydrocarbons, the thermal data obtained are independent of the atomic weight of carbon, 1 mole of ethylene being taken as equivalent to $2(18.0156) \mathrm{g}$ of water formed in the combustion and 1 mole of propylene to $3(18.0156) \mathrm{g}$ [5]. In reducing the data of the analytical combustion experiments, the molecular weight of $\mathrm{CO}_{2}$ was taken to be 44.010 [12].

\section{METHOD AND APPARATUS}

The calorimetric method employed in the present investigation has been described previously $[6,5]$. It has already been pointed out that in the "substitution" method of measuring heats of chemical reactions, neither the size of a degree of temperature nor the true heat capacity of the calorimeter system need be known. ${ }^{2}$ In order to emphasize further the substitutional nature of the calorimetric determinations, wherein the heat evolved by a measured amount of chemical reaction is compared with the heat evolved by a measured amount of electrical energy, using the calorimeter as the absorber and comparator of the two kinds of energy, the data on the electrical-energy equivalent of

1 The numbers in bruckets throughout the text refer to the references at the end of this paper.

${ }^{2}$ See p. 11 of reference [6] and p. 243 of reference [5]. 
the calorimeter are reduced to international joules per ohm increase in resistance of the given platinum resistance thermometer, as determined with the given resistance bridge, at the given mean temperature of the experiments.

Before the beginning of the present investigation, a new platinum resistance thermometer of the regular flat calorimetric type $[7,8]$ was installed. The constants on this thermometer, no. 262,214, were determined by the Thermometry Section of this Bureau to be as follows: $\delta=1.475, R_{0^{\circ} \mathrm{C}}=25.5740$, and $R_{100{ }^{\circ} \mathrm{C}}=35.5735$, NBS international ohms. For this thermometer, the relation between its resistance, expressed in international ohms, and the temperature in degrees centigrade is as follows:

$R=25.5740+0.101470 t-0.00001475 t^{2}$ international ohms; $d R / d t=0.101470-0.00002950 t$ international ohms degree ${ }^{-1}$; $d^{2} R / d t^{2}=-0.00002950$ international ohms degree ${ }^{-2}$.

And in terms of absolute ohms (taking 1 international ohm $=1.00046$ absolute ohms), the relation is as follows:

$R=25.5858+0.101517 t-0.00001476 t^{2}$ absolute ohms; $d R / d t=0.101517-0.00002952 t$ absolute ohms degree ${ }^{-1}$; $d^{2} R / d t^{2}=-0.00002952$ absolute ohms degree ${ }^{-2}$.

At the conclusion of the experiments on ethylene, and before the beginning of the experiments on propylene, a new bridge for measuring the resistance of the platinum thermometer was installed. This bridge was designed by E. F. Mueller [9] of this Bureau and made by the Eppley Laboratories, using substantially the electrical circuit described by Eppley [10]. The new bridge has all the coils of large resistance maintained at constant temperature in a metal block, so that the readings are practically independent of the room temperature. The commutator and several adjusting devices are incorporated into the bridge proper. These latter include an adjustable resistance for regulating the current through the bridge circuit so as to obtain a sensitivity on the galvanometer scale of an even number of $\mathrm{mm}$ per $\mathrm{ohm}$ (in the present assembly, the sensitivity was adjusted to $1 \mathrm{~mm}$ per $0.00001 \mathrm{ohm}$, or about $0.0001^{\circ} \mathrm{C}$ ); an adjustable resistance which can be placed in series or in parallel with the galvanometer in order to obtain proper damping; an extra $0.5-\mathrm{ohm}$ plug which can be used to remove $0.5 \mathrm{ohm}$ from the "known" arm of the bridge, in order that temperature changes of about $6^{\circ} \mathrm{C}$ or less can always be measured without disturbing the settings on the decade of $1-\mathrm{ohm}$ coils.

During the present investigation, the unsaturated standard cells previously used, in connection with the determination of the electrical power with the White "double" potentiometer, were replaced by two saturated standard cells kept at $30^{\circ} \mathrm{C}$ in a metal box similar to that described by Mueller and Stimson [15]. These standard cells were calibrated and kindly supplied to us by the Standard Cell Laboratory of this Bureau.

For the present experiments, there was used a new reaction vessel, which was identical with that used for propane, normal butane, normal pentane, and isobutane, and previously described [1], except that the burner tube and injector were altered in size to be suitable for the higher flame velocities of ethylene and propylene.

$7187-37-2$ 


\section{CHEMICAL PROCEDURE}

\section{PREPARATION AND PURITY OF THE HYDROCARBONS}

(a) ETHYLENE

The sample of ethylene used in the present investigation was prepared to our order by the Linde Air Products Co., Buffalo, N. Y., by the fractional distillation of petroleum products. In our laboratory, the ethylene was examined for impurities by means of Shepherd's differential vapor-pressure apparatus [11], and by determination of the ratio of carbon to hydrogen in the sample [12]. The Linde Air Products Co. reported that this sample of ethylene contained about 0.15 percent of ethane as impurity.

At the suggestion of Martin Shepherd, the differential vaporpressure measurements were carried out in such a way as to make them quantitative with respect to the amount of impurity in the entire sample. Since practically all of the impurity was less volatile than ethylene itself, it would be concentrated in the last distillation fractions. In several experiments, a 2-ml sample of liquid ethylene was separated by isothermal distillation into an "initial distillate" of 10 percent, a "second cut" of 35 percent, a "middle cut" of 10 percent, and a series of fractions from the "middle cut" to the "residue." The data given in table 1 were obtained in this manner, the "middle cut" being assumed to be pure ethylene. The uncertainties given in the table were estimated from the data. The method of making these calculations has already been described [11].

TABLE 1.-Data on the determination of the amount of impurity in ethylene by differential vapor-pressure measurements

\begin{tabular}{|c|c|c|c|c|}
\hline Series & Fraction & $\begin{array}{l}\text { Mole fraction } \\
\text { of impurity } \\
\text { in the given } \\
\text { fraction }\end{array}$ & $\begin{array}{l}\text { Corresponding } \\
\text { mole fraction } \\
\text { of impurity } \\
\text { in the entire } \\
\text { sample }\end{array}$ & $\begin{array}{l}\text { Total amount of the given im- } \\
\text { purity in the entire sample }\end{array}$ \\
\hline & $\begin{array}{c}\text { Percent } \\
\left\{\begin{array}{l}95 \text { to } 100 \ldots \\
85 \text { to } 95 \\
73 \text { to } 85 \ldots \\
55 \text { to } 73 \ldots\end{array}\right.\end{array}$ & $\begin{array}{r}0.0143 \\
.0089 \\
.0025 \\
\mathrm{a}(.0008)\end{array}$ & $\begin{array}{r}0.00072 \\
.00089 \\
.00030 \\
(.00013)\end{array}$ & $\begin{array}{c}\text { Mole fraction } \\
0.0020 \pm 0.0005 \text { (ethane) }\end{array}$ \\
\hline II.- & $\left\{\begin{array}{l}90 \text { to } 100 \ldots \\
80 \text { to } 90 \ldots \\
55 \text { to } 80 \ldots\end{array}\right.$ & $\begin{array}{r}0.0122 \\
.0054 \\
\mathrm{a}(.0016)\end{array}$ & $\begin{array}{c}.00122 \\
.00054 \\
(.00040)\end{array}$ & $.0022 \pm .0005$ (ethane) \\
\hline III... & 0 to $10 \ldots$ & .0015 & .00015 & $.0001_{5} \pm .0001_{0}$ (methane). \\
\hline
\end{tabular}

a These values were estimated by extrapolation from the other values.

Six experiments on the determination of the ratio of carbon to hydrogen in the sample of ethylene gave the following results: average amount of ethylene used per experiment, 0.030 mole; average value of the ratio, moles $\mathrm{CO}_{2} /$ moles $\mathrm{H}_{2} \mathrm{O}, 0.9986_{3}$; average deviation from the mean, $\pm 0.0001_{5}$; maximum deviation from the mean, $0.0003_{4}$; "uncertainty", calculated as in [5], $\pm 0.0001_{7}$.

With the amount of methane impurity taken to be that given by the differential vapor-pressure measurements, namely, $0.0001_{5} \pm 0.0001_{0}$ mole fraction, and with the value of the deviation from unity of the $\mathrm{C} / \mathrm{H}$ ratio giving the sum of methane plus ethane, the mole fraction of ethane is calculated to be $0.0026_{0} \pm 0.0003_{2}$. With the value for the mole fraction of ethane as determined by the vapor-pressure data taken to be $0.0021 \pm 0.0005$, and with these values weighted inversely as the squares of their estimated uncertainties, there is 
obtained for the mole fraction of ethane the weighted mean value $0.0024_{5} \pm 0.0002_{7}$.

\section{(b) PROPYLENE}

The Phillips Petroleum Co., at Bartlesville, Okla., supplied gratis to this laboratory $150 \mathrm{~g}$ of propylene prepared in their laboratory by the following steps: preparation of a "concentrate" of propylene by fractional distillation of gases from the petroleum cracking process; bromination of this "concentrate"; separation of the dibromides by distillation; regeneration of propylene from the dibromides with zinc and ethyl alcohol; and fractional distillation of the resulting propylene to yield a product measured to be 99.9 percent pure.

In our laboratory, this propylene was subjected to two successive distillations in a vacuum-jacketed spiral column coated internally with carborundum. This column, designed by Martin Shepard [13], had a linear length of about $55 \mathrm{~cm}$ and an actual distillation path along the spiral of about $600 \mathrm{~cm}$. In the first distillation, there were discarded an initial distillate of $5 \mathrm{ml}$ and a final residue of $20 \mathrm{ml}$, leaving a main body of $135 \mathrm{ml}$. This latter was subjected to a second distillation, which yielded an initial distillate of $5 \mathrm{ml}$, a final residue of 15 $\mathrm{ml}$, and a main body of $115 \mathrm{ml}$. Differential vapor-pressure measurements of the initial distillate and of the final residue against a middle cut of $10 \mathrm{ml}$ (taken at the midpoint of the distillation of the main body) indicated that this initial distillate of $5 \mathrm{ml}$ contained 0.0057 mole fraction of a more volatile impurity and the final residue of 15 $\mathrm{ml}$ contained 0.0020 mole fraction of a less volatile impurity. Assuming that the separation obtained with this column was substantially complete, these data would indicate that the entire sample contained, before the second distillation, about $0.0004_{3}$ mole fraction of impurity. The main body from the second distillation would therefore be expected to be substantially pure.

Four experiments on the determination of the ratio of carbon to hydrogen in the sample of propylene gave the following results (see p. 254): average amount of propylene used per experiment, 0.030 mole; average value of the ratio, moles $\mathrm{CO}_{2} /$ moles $\mathrm{H}_{2} \mathrm{O}, 0.9999_{7}$; average deviation from the mean, $\pm 0.0001_{8}$; maximum deviation from the mean, $0.0003_{0}$; "uncertainty", calculated as in [5], $\pm 0.0002_{4}$.

On the basis of the above data, it is concluded that the purity of this sample of propylene was such that, per mole of water formed, the heat of combustion of this sample would differ from that of an absolutely pure sample of propylene by less than 0.01 percent.

\section{PURITY OF THE COMBUSTION REACTION}

With the combustion reaction proceeding in the calorimetric-reaction vessel, the gaseous products of combustion, for both ethylene and propylene, were examined for the presence of carbon monoxide. ${ }^{3}$ No carbon monoxide was found in tests which would have detected an amount corresponding to about 0.00005 -mole fraction of the total carbon.

The ethylene was burned in an atmosphere of pure oxygen in the calorimetric-reaction vessel (see fig. 1 of reference [1]), but in the preliminary experiments with propylene it was found that the flame velocity was too great for its proper combustion in this burner. In order to avoid altering the burner, the flame velocity for the propylene combustions was reduced by diluting the oxygen with one-half its

\footnotetext{
${ }^{3}$ These tests were kindly made by C. Creitz, of the Gas Chemistry Section of this Bureau.
} 
volume of helium (the mixture of oxygen and helium being freed of combustible matter by a preliminary passage through hot copper at 500 to $600^{\circ} \mathrm{C}$, and then successively through Ascarite (a mixture of sodium hydroxide and asbestos), anhydrous magnesium perchlorate, and phosphorus pentoxide).

The purity of the ignition process was checked by running a series of ignitions and extinctions of the flame, in order to exaggerate greatly any abnormal effect present, and then comparing the small masses of carbon dioxide and water formed. In the ignitions with ethylene, the masses of carbon dioxide and water balanced, stoichiometrically, within the limits of error of the measurements. In the ignitions with propylene, however, there existed a difference in the increases in mass of the two absorption tubes corresponding to a stoichiometrical deficit of $0.0004_{9} \mathrm{~g}$ in the carbon dioxide tube, or a surplus of $0.0002_{0} \mathrm{~g}$ in the water tube, for each ignition operation carried out exactly as in the main analytical experiments. This small correction (amounting to about 0.012 percent) was applied to the data of the experiments on the determination of the carbon-hydrogen ratio (see p. 253). The corresponding correction to the energy of the reaction is discussed on page 256.

\section{DETERMINATION OF THE AMOUNT OF REACTION}

As in the previous experiments on hydrocarbons [1,14], the amount of reaction was determined from the mass of water formed in the combustion (see above). One mole (18.0156 g) of water was taken as equivalent to $\frac{1}{2}$ mole of $\mathrm{C}_{2} \mathrm{H}_{4}$ and to $\frac{1}{3}$ mole of $\mathrm{C}_{3} \mathrm{H}_{6}$, and the resulting values of the heats of combustion are, therefore, independent of the atomic weight of carbon.

\section{CALORIMETRIC PROCEDURE}

\section{ELECTRICAL-ENERGY EXPERIMENTS}

The data of the electrical-energy experiments for ethylene are given in table 2, where the various quantities have the same significance as in former reports (see p. 17 of reference [6]), except that the electricalenergy equivalent of the calorimeter system is now expressed in terms of international joules per ohm increase in resistance of the given thermometer as read on the given bridge, the change in resistance being for the given mean temperature of the experiments.

TABLE 2.-Calorimetric results of the electrical-energy experiments for ethylene

\begin{tabular}{|c|c|c|c|c|c|c|c|c|}
\hline Experiment & $\Delta R 1$ & $k$ & $K$ & $U$ & $\begin{array}{l}\text { Electrical } \\
\text { energy? }\end{array}$ & $\begin{array}{l}\text { Mass of } \\
\text { calo- } \\
\text { rimeter } \\
\text { water }\end{array}$ & $\begin{array}{c}\text { Electrical- } \\
\text { energy equiv- } \\
\text { alent of } \\
\text { calorimeter } \\
\text { system }^{3}\end{array}$ & $\begin{array}{c}\text { Deviation } \\
\text { from } \\
\text { mean }\end{array}$ \\
\hline & $\begin{array}{c}\text { Ohm } \\
0.412006 \\
.410889 \\
.410894 \\
.410133\end{array}$ & $\begin{array}{c}\min -1 \\
0.001948 \\
.001948 \\
.001946 \\
.001935\end{array}$ & $\begin{array}{c}\text { Ohm } \\
0.007963 \\
.008013 \\
.008015 \\
.008019\end{array}$ & $\begin{array}{c}\text { Ohm } \\
-0.000221 \\
-.000381 \\
-.000118 \\
-.000369\end{array}$ & $\begin{array}{c}\begin{array}{c}\text { International } \\
\text { joules }\end{array} \\
60748.3 \\
60648.5 \\
60700.3 \\
60704.4\end{array}$ & $\begin{array}{c}\mathrm{g} \\
3537.97 \\
3543.00 \\
3546.86 \\
3551.70\end{array}$ & $\begin{array}{r}\text { International } \\
\text { joules/inter- } \\
\text { national ohm } \\
150767.3 \\
{[150686.7} \\
150751.9 \\
150754.0\end{array}$ & $\begin{array}{r}\text { Joules/ohm } \\
8.3 \\
-7.1 \\
-5.0\end{array}$ \\
\hline $\begin{array}{l}5 \\
6 \\
7\end{array}$ & $\begin{array}{r}.410749 \\
.410181 \\
.411637\end{array}$ & $\begin{array}{r}.001949 \\
.001958 \\
.001954\end{array}$ & $\begin{array}{l}.008022 \\
.008092 \\
.008026\end{array}$ & $\begin{array}{l}-.000092 \\
-.000342 \\
-.000129\end{array}$ & $\begin{array}{l}60736.6 \\
60780.9 \\
60799.6\end{array}$ & $\begin{array}{l}3550.47 \\
3547.88 \\
3545.58\end{array}$ & $\begin{array}{l}150758.8 \\
150747.6 \\
150774.1\end{array}$ & $\begin{array}{r}-0.1 \\
-11.4 \\
15.1\end{array}$ \\
\hline Mean & (n) & & 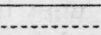 & & 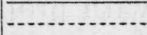 & $\ldots$ & 150759.0 & \pm 7.8 \\
\hline
\end{tabular}

1 The average temperature of the calorimeter was $25.00^{\circ} \mathrm{C}$ for experiments $3,4,5$, and 6 , and $25.01^{\circ} \mathrm{C}$ for experiments 1,2 , and 7 .

2 The time of electrical-energy input was 1140.00 seconds in each experiment.

${ }^{3}$ For $3550.00 \mathrm{~g}$ of water in the calorimeter and an average temperature of $25.00^{\circ} \mathrm{C}$. (See p. 250 regarding the units.) 
For the ethylene experiments, thermometer no. 262,214 was used in conjunction with bridge no. 47,669 (Leeds \& Northrup), the resistance coils of which are evaluated in international ohms. The "precision uncertainty" [5] of the final value from these experiments is $\pm 0.005_{4}$ percent.

The data of the electrical-energy experiments for propylene are given in table 3. For these experiments, thermometer no. 262,214 was used in conjunction with bridge no. 404 (Eppley), the resistance coils of which are evaluated in terms of absolute ohms as given by the relation, 1 NBS international $\mathrm{ohm}=1.00046$ absolute ohms. The "precision uncertainty" [5] of the final value from these experiments is $\pm 0.005_{3}$ percent.

TABLE 3.-Calorimetric results of the electrical-energy experiments for propylene

\begin{tabular}{|c|c|c|c|c|c|c|c|c|}
\hline $\begin{array}{c}\text { Experi- } \\
\text { ment }\end{array}$ & $\Delta R^{1}$ & $k$ & $K$ & $U$ & $\begin{array}{l}\text { Electrical } \\
\text { energy ? }\end{array}$ & $\begin{array}{l}\text { Mass of } \\
\text { calor- } \\
\text { imeter } \\
\text { water }\end{array}$ & $\begin{array}{c}\begin{array}{c}\text { Electrical- } \\
\text { energy } \\
\text { equivalent } \\
\text { of } \\
\text { calorimeter } \\
\text { system }^{3}\end{array}\end{array}$ & $\begin{array}{c}\text { Deviation } \\
\text { from } \\
\text { mean }\end{array}$ \\
\hline - & $\begin{array}{c}\text { Ohm } \\
0.400340 \\
.397638 \\
.396597 \\
.396470 \\
.397062\end{array}$ & $\begin{array}{c}\min ^{-1} \\
0.001971 \\
.001960 \\
.001950 \\
.001948 \\
.001968\end{array}$ & $\begin{array}{l}\text { Ohm } \\
0.010689 \\
.010369 \\
.010654 \\
.010438 \\
.010646\end{array}$ & $\begin{array}{c}\text { Ohm } \\
0.000088 \\
.000289 \\
.000136 \\
.000184 \\
.000082\end{array}$ & $\begin{array}{r}\text { International } \\
\text { joules } \\
58697.2 \\
58144.5 \\
58116.2 \\
58041.7 \\
58056.8\end{array}$ & $\begin{array}{c}\mathrm{g} \\
3548.58 \\
3538.83 \\
3548.25 \\
3543.39 \\
3540.91\end{array}$ & $\begin{array}{c}\text { International } \\
\text { joules/abso- } \\
\text { lute ohm } \\
150733.2 \\
150712.7 \\
150707.9 \\
150700.3 \\
{[150652.2]}\end{array}$ & $\begin{array}{r}\text { Joules/ } \\
\text { ohm } \\
21.4 \\
0.9 \\
-3.9 \\
-11.5 \\
\end{array}$ \\
\hline $\begin{array}{l}6 \\
7 \\
8 \\
9\end{array}$ & $\begin{array}{l}.395236 \\
.398970 \\
.399980 \\
.398560\end{array}$ & $\begin{array}{l}.001947 \\
.001948 \\
.001947 \\
.001952\end{array}$ & $\begin{array}{l}.010545 \\
.010292 \\
.010353 \\
.010300\end{array}$ & $\begin{array}{l}.000214 \\
.000143 \\
.000095 \\
.000116\end{array}$ & $\begin{array}{l}57970.1 \\
58598.6 \\
58613.3 \\
58462.7\end{array}$ & $\begin{array}{l}3551.30 \\
2552.59 \\
3544.30 \\
3548.14\end{array}$ & $\begin{array}{l}150723.0 \\
150711.2 \\
150707.0 \\
150698.1\end{array}$ & $\begin{array}{r}11.2 \\
0.1 \\
-4.9 \\
-13.7\end{array}$ \\
\hline Mean. & & & & & & & 150711.8 & \pm 8. \\
\hline
\end{tabular}

1 The average temperature of the calorimeter was $24.98^{\circ} \mathrm{C}$ for experiment $6 ; 24.99^{\circ} \mathrm{C}$ for experiments $2,3,4,5$, and $7 ; 25.00^{\circ} \mathrm{C}$ for experiments 8 and 9 ; and $25.01^{\circ} \mathrm{C}$ for experiment 1 .

2 The time of electrical-energy input was 1560.00 seconds in each experiment.

${ }^{3}$ For $3550.00 \mathrm{~g}$ of water in the calorimeter and an average temperature of $25.00^{\circ} \mathrm{C}$. (See p. 250 regarding units.)

\section{CORRECTION EXPERIMENTS}

The process of ignition and extinction of the flame was checked, as in the previous investigations, by performing a series of ignitions and extinctions of the flame, and making a thermal balance of the sources and sinks of energy, namely the "reaction", "vaporization", "gas", and "spark" energies, each of which was evaluated as before [1].

For a series of seven ignitions and extinctions of the flame with ethylene, carried out under the same conditions as in the main calorimetric combustion experiments, the thermal quantities were out of balance by only 6.4 joules. This corresponds to 0.9 joule for each ignition of the flame, or to about 1 part in 70,000 in the total energy of the main calorimetric combustion experiments. This difference is well within the limits of error of the measurements.

For a series of six ignitions and extinctions of the flame with propylene, it was found that, assuming the increase in mass of the water absorption tube to measure accurately the amount of propylene burned to carbon dioxide and water in these experiments, in which the amount of reaction was very small, the thermal quantities were out of balance by 31.7 joules, which corresponds to a sink of energy of 5.3 joules for each ignition operation carried out exactly as in the 
main calorimetric combustion experiments. (This "impurity" in the ignition process for propylene may also be taken care of by assuming a surplus of $0.0001_{4} \mathrm{~g}$ in the increase in mass of the water absorption tube above that amount representing the true amount of reaction.) Because this small difference was larger than the experimental error of the determination, due account of it was taken by subtracting 5.3 joules from the pure "spark" energy in each main calorimetric combustion experiment to obtain a net "ignition" energy. Since the total magnitude of this correction is about 0.009 percent of the total energy of a main calorimetric combustion experiment, its value needs to be known only to about one-fourth of itself to be entirely without significance in the results. Furthermore, this correction is of the proper sign and magnitude as would be deduced from the direction and amount of the unbalance in the masses of carbon dioxide and water obtained in the ignition operation (see p. 254).

\section{REACTION EXPERIMENTS}

The data of the reaction experiments for ethylene are given in table 4. The "precision uncertainty" [5] of the final value from these experiments is \pm 0.014 percent. The correction for the impurity in the ethylene (see p. 252) is $1.44 \pm 0.16$ kilojoules per mole.

The data of the reaction experiments for propylene are given in table 5. The "precision uncertainty" [5] of the final value from these experiments is \pm 0.028 percent.

$\mathrm{T}_{A \mathrm{BLE}}$ 4.-Calorimetric results of the reaction experiments for ethylene

\begin{tabular}{|c|c|c|c|c|c|c|c|c|c|c|c|}
\hline $\begin{array}{l}\text { Ex- } \\
\text { peri- } \\
\text { ment }\end{array}$ & $\Delta R^{1}$ & $k$ & $K$ & $U$ & $\begin{array}{l}\text { Electrical- } \\
\text { energy } \\
\text { equivalent } \\
\text { of calorim- } \\
\text { eter sys- } \\
\text { tem }{ }^{2}\end{array}$ & $\begin{array}{l}\text { "Gas" } \\
\text { energy }\end{array}$ & $\begin{array}{l}\text { "Igni-" } \\
\text { tion" } \\
\text { energy }\end{array}$ & "Vapor-" & $\begin{array}{c}\text { Mass of } \\
\text { water } \\
\text { formed } \\
\text { in the } \\
\text { reaction }\end{array}$ & $\begin{array}{c}\text { Heat of } \\
\text { combus- } \\
\text { tion }{ }^{3} \text { at } \\
25^{\circ} \mathrm{C}\end{array}$ & $\begin{array}{l}\text { Devia- } \\
\text { tion } \\
\text { from } \\
\text { mean }\end{array}$ \\
\hline & $\begin{array}{r}\text { Ohm } \\
0.403710 \\
.407606 \\
.407921 \\
.409739 \\
.407826\end{array}$ & $\begin{array}{c}\min ^{-1} \\
0.001964 \\
.001975 \\
.001973 \\
.001966 \\
.001977\end{array}$ & $\begin{array}{c}\text { Ohm } \\
0.011247 \\
.011865 \\
.011321 \\
.012783 \\
.012298\end{array}$ & $\begin{array}{c}\text { Ohm } \\
0.000091 \\
.000087 \\
.000103 \\
.000080 \\
-.000087\end{array}$ & 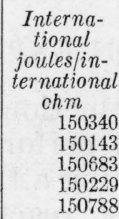 & $\begin{array}{r}\text { Joules } \\
16.8 \\
1.3 \\
1.3 \\
1.6 \\
-2.5\end{array}$ & $\begin{array}{r}\text { Joules } \\
17.1 \\
10.8 \\
10.8 \\
10.8 \\
10.8\end{array}$ & $\begin{array}{r}\text { Joules } \\
405.6 \\
404.9 \\
418.8 \\
399.0 \\
373.4\end{array}$ & $\begin{array}{c}g \\
1.51728 \\
1.52849 \\
1.52997 \\
1.53396 \\
1.53459\end{array}$ & 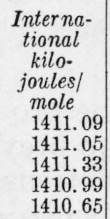 & $\begin{array}{c}\text { Kilo- } \\
\text { joules/ } \\
\text { mole } \\
0.12 \\
.08 \\
.36 \\
.02 \\
-.32\end{array}$ \\
\hline & $\begin{array}{r}.408878 \\
.410182 \\
.408469 \\
.407582\end{array}$ & $\begin{array}{l}.001988 \\
.001983 \\
.001979 \\
.001986\end{array}$ & $\begin{array}{l}.012314 \\
.012901 \\
.012672 \\
.013690\end{array}$ & $\begin{array}{l}.000205 \\
.000099 \\
.000099 \\
.000342\end{array}$ & $\begin{array}{l}150317 \\
150720 \\
150628 \\
150336\end{array}$ & $\begin{array}{r}-3.0 \\
2.0 \\
4.0 \\
5.6\end{array}$ & $\begin{array}{l}11.7 \\
13.5 \\
14.4 \\
17.1\end{array}$ & $\begin{array}{l}370.2 \\
407.6 \\
415.6 \\
418.5\end{array}$ & $\begin{array}{l}1.53195 \\
1.54051 \\
1.53487 \\
1.52311\end{array}$ & $\begin{array}{r}1411.24 \\
1410.76 \\
{[1409.95]} \\
1410.63\end{array}$ & $\begin{array}{r}.27 \\
-.21 \\
-.34\end{array}$ \\
\hline Mean. & & & & & & & & & & 1410.97 & \pm 0.22 \\
\hline
\end{tabular}

1 The average temperature of the calorimeter was $25.00^{\circ} \mathrm{C}$ for experiments $2,3,4,5,6,8$, and $9 ; 24.97^{\circ} \mathrm{C}$ for experiment 1 ; and $25.01^{\circ} \mathrm{C}$ for experiment 7 .

${ }_{2}$ Includes the heat capacity of one-half the mass of liquid water formed in the reaction. (See p. 250 regarding units.)

${ }^{3}$ To each value has been added 1.44 kilojoules per mole as a correction for the impurity in the ethylene. (See p. 252.) 
$\mathrm{T}_{\mathrm{ABLE}}$ 5.-Calorimetric results of the reaction experiments for propylene

\begin{tabular}{|c|c|c|c|c|c|c|c|c|c|c|c|}
\hline $\begin{array}{l}\text { Ex- } \\
\text { peri- } \\
\text { ment }\end{array}$ & $\Delta R^{1}$ & $k$ & $K$ & $U$ & $\begin{array}{l}\text { Electrical- } \\
\text { energy } \\
\text { equivalent } \\
\text { of calori- } \\
\text { metric } \\
\text { system }^{2}\end{array}$ & $\begin{array}{l}\text { "Gas" } \\
\text { energy }\end{array}$ & $\begin{array}{l}\text { "Igni- } \\
\text { tion" } \\
\text { energy }\end{array}$ & $\begin{array}{l}\text { "Vapor- } \\
\text { ization" } \\
\text { energy }\end{array}$ & $\begin{array}{c}\text { Mass of } \\
\text { water } \\
\text { formed } \\
\text { in the } \\
\text { reaction }\end{array}$ & $\begin{array}{l}\text { Heat of } \\
\text { combus- } \\
\text { tion at } \\
25^{\circ} \mathrm{C}\end{array}$ & $\begin{array}{l}\text { Devia- } \\
\text { tion } \\
\text { from } \\
\text { mean }\end{array}$ \\
\hline & \begin{tabular}{|c|} 
Ohm \\
0.398833 \\
.399424 \\
.399060 \\
.397818
\end{tabular} & $\begin{array}{c}\min ^{-1} \\
0.001967 \\
.001971 \\
.001947 \\
.001986\end{array}$ & $\begin{array}{c}\text { Ohm } \\
0.010694 \\
.010005 \\
.009625 \\
.010061\end{array}$ & $\begin{array}{c}\text { Ohm } \\
0.000061 \\
.000150 \\
.000088 \\
.000377\end{array}$ & $\begin{array}{c}\text { Interna- } \\
\text { tional } \\
\text { joules/ab- } \\
\text { solute } \\
\text { ohm } \\
150405 \\
150567 \\
150785 \\
150440\end{array}$ & $\begin{array}{c}\text { Joules } \\
0.0 \\
0 \\
0 \\
3.5\end{array}$ & $\begin{array}{r}\text { Joules } \\
18.7 \\
22.7 \\
24.7 \\
18.7\end{array}$ & \begin{tabular}{|c|} 
Joules \\
569.3 \\
481.0 \\
496.6 \\
486.5
\end{tabular} & $\begin{array}{c}\mathrm{g} \\
1.54783 \\
1.55179 \\
1.55441 \\
1.54366\end{array}$ & $\begin{array}{c}\text { Interna- } \\
\text { tional } \\
\text { kilo- } \\
\text { joules! } \\
\text { mole } \\
2057.34 \\
2057.31 \\
2057.67 \\
2056.68\end{array}$ & $\begin{array}{c}\text { Kilo- } \\
\text { joules/ } \\
\text { mole } \\
-0.08 \\
-.11 \\
.25 \\
-.74\end{array}$ \\
\hline $7 \ldots$ & $\begin{array}{l}.398701 \\
.399116 \\
.397725 \\
\end{array}$ & $\begin{array}{l}.001961 \\
.001953 \\
.001964\end{array}$ & $\begin{array}{l}.010681 \\
.010326 \\
.010651\end{array}$ & $\begin{array}{l}.000326 \\
.000058 \\
.000279\end{array}$ & $\begin{array}{l}150603 \\
150628 \\
150616\end{array}$ & $\begin{array}{l}1.7 \\
1.7 \\
0\end{array}$ & $\begin{array}{l}12.7 \\
10.7 \\
12.7\end{array}$ & $\begin{array}{l}555.6 \\
529.8 \\
520.0\end{array}$ & $\begin{array}{l}1.54785 \\
1.55068 \\
1.54441\end{array}$ & $\begin{array}{l}2057.63 \\
2058.85 \\
2056.48\end{array}$ & $\begin{array}{r}.21 \\
1.43 \\
-.94\end{array}$ \\
\hline So & & & & & & & & & & 2057.42 & \pm 0.54 \\
\hline
\end{tabular}

1 The average temperature of the calorimeter was $25.01^{\circ} \mathrm{C}$ for experiment 1 , and $25.00^{\circ} \mathrm{C}$ for experiments $2,3,4,5,6$, and 7 .

2 Includes the heat capacity of one-half the mass of liquid water formed in the reaction. (See p. 250 regarding units.)

\section{RESULTS OF THE PRESENT INVESTIGATION}

The data of the present investigation yield, for the heats of combustion of ethylene and propylene, according to the reaction

$$
\mathrm{C}_{n} \mathrm{H}_{2 n}(\mathrm{~g})+3 n / 2 \mathrm{O}_{2}(\mathrm{~g})=n \mathrm{CO}_{2}(\mathrm{~g})+n \mathrm{H}_{2} \mathrm{O} \text { (liq) }
$$

at $25^{\circ} \mathrm{C}$ and a constant pressure of 1 atmosphere, the values shown in table 6 . The uncertainties in the final values were computed as for the previous data [5].

TABLE 6.-Results of the present investigation

Reaction: $\mathrm{C}_{n} \mathrm{H}_{2 n}(\mathrm{~g})+3 n / 2 \mathrm{O}_{2}(\mathrm{~g})=n \mathrm{CO}_{2}(\mathrm{~g})+n \mathrm{H}_{2} \mathrm{O}$ (liq)

\begin{tabular}{|c|c|c|c|}
\hline \multirow[b]{2}{*}{$\begin{array}{l}\text { Ethylene } \\
\text { Propylene. }\end{array}$} & \multirow{2}{*}{$\begin{array}{c}\text { Formula } \\
\\
\mathrm{C}_{2} \mathrm{H}_{4} \ldots \ldots \\
\mathrm{C}_{3} \mathrm{H}_{6} \ldots \ldots\end{array}$} & \multicolumn{2}{|c|}{$\begin{array}{c}\text { Heat of combustion } \\
-\Delta H \text { at } 25^{\circ} \mathrm{C} \text { and } 1 \text { atmosphere }\end{array}$} \\
\hline & & $\begin{array}{l}\text { International } \\
\text { kilojoules } 1 \\
1410.97 \pm 0.30 \\
2057.42 \pm 0.62\end{array}$ & $\begin{array}{l}\text { Kilocalories } \\
\text { per mole } 2 \\
337.28 \pm 0.07 \\
491.82 \pm 0.15\end{array}$ \\
\hline
\end{tabular}

1 See p. 250

2 See p. 250

\section{DATA OF PREVIOUS INVESTIGATIONS}

\section{ETHYLENE}

Data on the heat of combustion of ethylene have been reported by Dulong [16], Grassi [17], Favre and Silbermann [18], Andrews [19], Berthelot [20], Berthelot and Matignon [21], Thomsen [22], and Mixter [23]. The first four investigations may now be considered as of historical importance only.

The data of Berthelot and Matignon [21] (see also Berthelot [20]) have already been reviewed (see p. 631 of reference [24]), and yield 
for the heat of combustion of ethylene according to reaction (1), at $25^{\circ} \mathrm{C}$ and 1 atmosphere, $-\Delta H=1426.5 \pm 6.7$ international kilojoules or $341.0 \pm 1.6$ kilocalories per mole.

The data of Thomsen [22] have also been reviewed previously (see p. 631 of reference [24]), and yield for the heat of combustion of ethylene according to reaction (1), at $25^{\circ} \mathrm{C}$ and 1 atmosphere, $-\Delta H=1392.6 \pm 3.3$ international kilojoules or $332.9 \pm 0.8$ kilocalories per mole.

Mixter [23] performed three experiments on the combustion of gaseous ethylene (containing several percent of hydrogen) in a bomb at constant volume at about $18^{\circ} \mathrm{C}$. In the three experiments the amount of hydrogen present was reported to be $6.3,2.8$, and 3 percent, respectively; and the amount of ethylene, in moles, was deduced from the composition of the gas, the volume of the bomb, and the pressure and temperature at which the bomb was closed. About $1 / 40$ mole of ethylene was used in each experiment, and the heat evolved was corrected for the combustion of the given amount of hydrogen. With modern values for $P V / R T$ for ethylene at about $18^{\circ} \mathrm{C}$ and 1 atmosphere, ${ }^{4}$ for the heat of combustion of hydrogen, and for the unit of energy [5], there is obtained, from Mixter's data, for the heat evolved in the combustion of ethylene, according to reaction (1) at $25^{\circ} \mathrm{C}$ and a constant pressure of 1 atmosphere, $-\Delta H=1442 \pm 10$ international kilojoules or $344.8 \pm 2.4$ kilocalories per mole. The uncertainty here is calculated according to [5] without taking into account possible systematic errors arising from the calorimetry or chemistry of Mixter's experiments.

It is also possible to calculate a value for the heat of combustion of ethylene from modern values for the heats of combustion of ethane and hydrogen and the heat of hydrogenation of ethylene:

$$
\begin{gathered}
\mathrm{C}_{2} \mathrm{H}_{6}(\mathrm{~g})+3 \frac{1}{2} \mathrm{O}_{2}(\mathrm{~g})=2 \mathrm{CO}_{2}(\mathrm{~g})+3 \mathrm{H}_{2} \mathrm{O}(\mathrm{liq}) \\
\mathrm{H}_{2}(\mathrm{~g})+1 / 2 \mathrm{O}_{2}(\mathrm{~g})=\mathrm{H}_{2} \mathrm{O} \text { (liq) } \\
\mathrm{C}_{2} \mathrm{H}_{4}(\mathrm{~g})+\mathrm{H}_{2}(\mathrm{~g})=\mathrm{C}_{2} \mathrm{H}_{6}(\mathrm{~g})
\end{gathered}
$$

The sum of reactions (2) and (4) less (3) yields

$$
\mathrm{C}_{2} \mathrm{H}_{4}(\mathrm{~g})+3 \mathrm{O}_{2}(\mathrm{~g})=2 \mathrm{CO}_{2}(\mathrm{~g})+2 \mathrm{H}_{2} \mathrm{O} \text { (liq) }
$$

With the value of $-\Delta H$ at $25^{\circ} \mathrm{C}$ and 1 atmosphere for reactions (2) and (3) taken from the previously published data of this laboratory $[6,1]$ as $1559.57 \pm 0.44$ and $285.775 \pm 0.040$ international kilojoules per mole, respectively, and for reaction (4) from the data of Kistiakowsky, Vaughan, et al. $[3,4,24]$ as $136.45 \pm 0.25$ international kilojoules per mole, there is obtained for reaction (5) the value $-\Delta H=1410.25 \pm 0.52$ international kilojoules or $337.11 \pm 0.13$ kilocalories per mole, at $25^{\circ} \mathrm{C}$ and 1 atmosphere. The value taken for reaction (4) is the average of the two close values previously deduced [24] from the direct hydrogenation experiments of Kistiakowsky, Vaughan, et al. [3], corrected $(+0.022$ percent) to the new (44.010) molecular weight of carbon dioxide.

The various experimental values for the heat of combustion of ethylene are shown together in figure 1.

4 This value was kindly supplied by C. S. Cragoe, of this Bureau. 


\section{PROPYLENE}

Data on the heat of combustion of propylene have been reported by Berthelot [20], Berthelot and Matignon [21], and Thomsen [22].

Berthelot and Matignon [21] (see also Berthelot [20]) performed three experiments on the heat of combustion of propylene in a bomb at constant volume at about $15^{\circ} \mathrm{C}$. The amount of reaction was

ETHYLENE

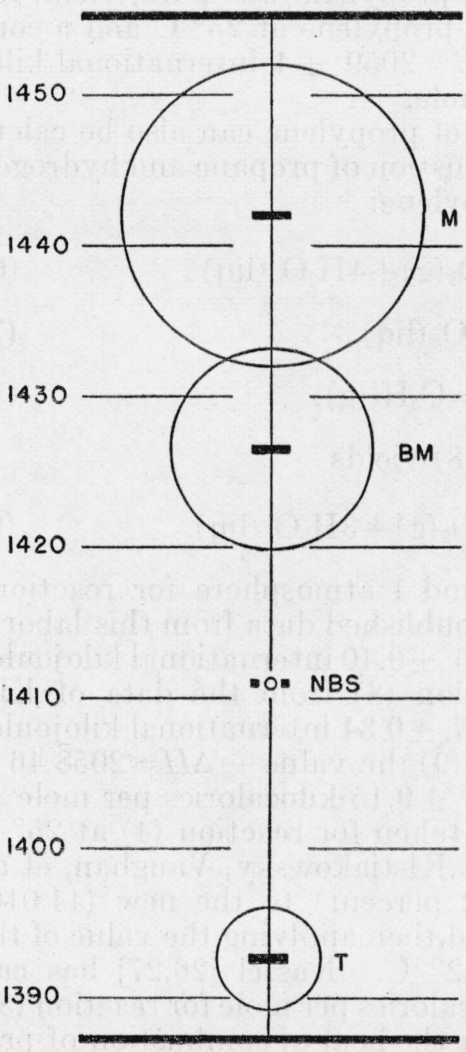

PROPYLENE

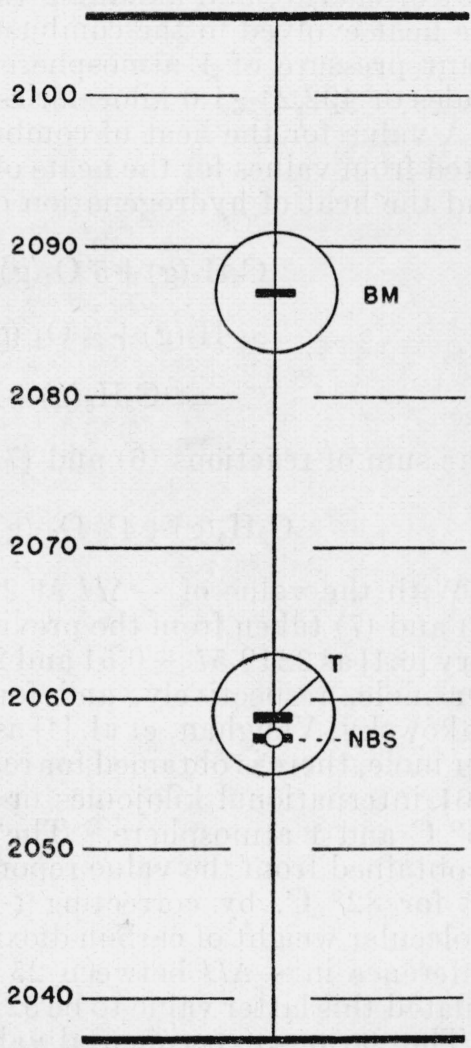

Figure 1.-Plot of the various data on the heats of combustion of ethylene and propylene.

The scale of ordinates gives the heat of combustion, at $25^{\circ} \mathrm{C}$ and a constant pressure of 1 atmosphere, in international kilojoules per mole. The average values of each investigation, together with the estimated uncertainties (measured by the radii of the respective circles), are indicated as follows: T, Thomsen [22]; BM, Berthelot and Matignon [21]; M, Mixter [23]; NBS, present investigation.

determined both from the volume of propylene burned and the mass of carbon dioxide formed, though the latter datum was apparently lost for the second experiment. The respective values by the two methods agreed within about 0.1 percent, although no information is given as to the value used for $P V / R T$ for propylene. In terms of the modern unit of energy, these data yield for the heat of combustion of propylene, according to reaction (1) at $25^{\circ} \mathrm{C}$ and a constant pressure of 1 atmosphere, $-\Delta H=2087 \pm 4$ international kilojoules or $498.9 \pm 1.0$ kilocalories per mole. 
Thomsen [22] performed four experiments on the heat of combustion of propylene in a flame calorimeter at constant pressure and about $18^{\circ} \mathrm{C}$, the amount of reaction being determined from the mass of carbon dioxide formed. Thomsen used two different samples of propylene, both prepared chemically, and his values for the ratio of carbon to hydrogen, expressed as the ratio of moles of $\mathrm{CO}_{2}$ per mole of $\mathrm{H}_{2} \mathrm{O}$, were $0.983_{3}, 0.991_{4}, 1.006_{7}$, and $1.002_{0}$ for one sample and $1.005_{0}$ for the other. Thomsen's data, converted to the modern unit of energy, and assuming that the propylene was pure, yield, for the heat evolved in the combustion of propylene at $25^{\circ} \mathrm{C}$ and a constant pressure of 1 atmosphere, $-\Delta H=2059 \pm 4$ international kilojoules or $492.2 \pm 1.0$ kilocalories per mole.

A value for the heat of combustion of propylene can also be calculated from values for the heats of combustion of propane and hydrogen and the heat of hydrogenation of propylene:

$$
\begin{gathered}
\mathrm{C}_{3} \mathrm{H}_{8}(\mathrm{~g})+5 \mathrm{O}_{2}(\mathrm{~g})=3 \mathrm{CO}_{2}(\mathrm{~g})+4 \mathrm{H}_{2} \mathrm{O} \text { (liq) } \\
\mathrm{H}_{2}(\mathrm{~g})+1 / 2 \mathrm{O}_{2}(\mathrm{~g})=\mathrm{H}_{2} \mathrm{O} \text { (liq) } \\
\mathrm{C}_{3} \mathrm{H}_{6}(\mathrm{~g})+\mathrm{H}_{2}(\mathrm{~g})=\mathrm{C}_{3} \mathrm{H}_{8}(\mathrm{~g}) .
\end{gathered}
$$

The sum of reactions (6) and (7) less (8) yields

$$
\mathrm{C}_{3} \mathrm{H}_{6}(\mathrm{~g})+4 \frac{1}{2} \mathrm{O}_{2}(\mathrm{~g})=3 \mathrm{CO}_{2}(\mathrm{~g})+3 \mathrm{H}_{2} \mathrm{O} \text { (liq). }
$$

With the value of $-\Delta H$ at $25^{\circ} \mathrm{C}$ and 1 atmosphere for reactions (6) and (7) taken from the previously published data from this laboratory [6,1] as $2219.57 \pm 0.51$ and $285.775 \pm 0.40$ international kilojoules per mole, respectively, and for reaction (8) from the data of Kistiakowsky, Vaughan, et al. [4] as $124.67 \pm 0.34$ international kilojoules per mole, there is obtained for reaction (9) the value $-\Delta H=2058.46 \pm$ 0.61 international kilojoules or $492.07 \pm 0.15$ kilocalories per mole at $25^{\circ} \mathrm{C}$ and 1 atmosphere. The value taken for reaction (4) at $25^{\circ} \mathrm{C}$ is obtained from the value reported by Kistiakowsky, Vaughan, et al. [3] for $82^{\circ} \mathrm{C}$, by correcting ( +0.022 percent) to the new (44.010) molecular weight of carbon dioxide, and then applying the value of the difference in $-\Delta H$ between 25 and $82^{\circ} \mathrm{C}$. Kassel $[26,27]$ has calculated this latter value to be $321 \pm 40$ calories per mole for reaction (8).

The various experimental values for the heat of combustion of propylene are shown together in figure 1.

\section{CONCLUSION}

In table 7 are displayed the various values for the heats of combustion of ethylene and propylene. The values marked ICT [25] are those given in the International Critical Tables as the then "best" values for these thermal constants. The agreement of Thomsen's value for propylene with that from the present investigation appears to be fortuitous. The agreement of the "Calculated" values with those from the present work indicates an accord among the heats of combustion of hydrogen, ethane, and propane, as measured at the National Bureau of Standards $[6,1]$ and the heats of hydrogenation of ethylene and propylene as measured at Harvard [3, 4]. 
TABLE 7.-Values for the heats of combustion of ethylene and of propylene

\begin{tabular}{|c|c|c|c|c|}
\hline \multirow[b]{2}{*}{ Source } & \multicolumn{2}{|c|}{ Ethylene } & \multicolumn{2}{|c|}{ Propylene } \\
\hline & $\begin{array}{c}-\Delta H \text { at } 25^{\circ} \mathrm{C} \\
\text { and } 1 \text { atm }\end{array}$ & $\begin{array}{l}\text { Difference from } \\
\text { value of present } \\
\text { investigation }\end{array}$ & $\begin{array}{c}-\Delta H \text { at } 25^{\circ} \mathrm{C} \\
\text { and } 1 \mathrm{~atm}\end{array}$ & $\begin{array}{l}\text { Difference from } \\
\text { value of present } \\
\text { investigation }\end{array}$ \\
\hline $\begin{array}{l}\text { Berthelot and Matignon [21] } \\
\text { Thomsen [22] } \\
\text { Mixter [23] } \\
\text { ICT [25] } \\
\text { Calculated (see p. } 258,260 \text { ) } \\
\text { National Bureau of Standards }\end{array}$ & $\begin{array}{c}\text { Ki!ocalories per } \\
\text { mole } 1 \\
341.0 \pm 1.6 \\
332.9 \pm 0.8 \\
344.8 \pm 2.4 \\
332 \pm ? \\
337.11 \pm 0.13 \\
337.28 \pm 0.07\end{array}$ & $\begin{array}{c}\text { Kilocalories per } \\
\text { mole } \\
3.7 \pm 1.7 \\
-4.4 \pm 0.9 \\
7.5 \pm 2.5 \\
-5.3 \pm ? \\
-0.17 \pm 0.20\end{array}$ & $\begin{array}{c}\text { Kilocalories per } \\
\text { mole } 1 \\
498.9 \pm 1.0 \\
492.2 \pm 1.0 \\
490.0 \pm ? \\
492.07 \pm 0.15 \\
491.82 \pm 0.15\end{array}$ & $\begin{array}{c}\text { Kilocalories per } \\
\text { mole } \\
7.1 \pm 1.2 \\
0.3 \pm 1.2 \\
-1.8 \pm ? \\
0.25 \pm 0.29\end{array}$ \\
\hline
\end{tabular}

1 Converted from international kilojoules with the factor $1 / 4.1833$

From a consideration of the present and previous data $[1,2,6,14]$ from this laboratory, it is apparent that values for the heats of combustion of hydrocarbons based upon data obtained half a century ago usually carry an uncertainty much greater than is indicated by the "internal" consistency of the data from a given investigation. This is due to the fact that these early investigators had not the advantages of pure materials and accurate calorimetric apparatus, such as are available today.

As discussed in the introduction of this paper, the data of the present investigation will be used in conjunction with other data to obtain values for the heats of combustion and formation of all the normal olefin (alkene-1) hydrocarbons in the gaseous state. These values will appear in a forthcoming publication.

The authors wish to express their gratitude to the Phillips Petroleum Co., Bartlesville, Okla., for supplying the stock of propylene, to Martin Shepherd for advice in the distillation and determination of the purity of the samples, and to E. F. Mueller for advice and aid in connection with the installation and calibration of the new resistance thermometer bridge.

\section{REFERENCES}

[1] F. D. Rossini, BS J. Research 12, 735 (1934) RP686.

[2] F. D. Rossini, J. Research NBS 13, 21 (1934) RP692.

[3] G. B. Kistiakowsky, H. Romeyn, Jr., J. R. Ruhoff, H. A. Smith, and W. E. Vaughan, J. Am. Chem. Soc. 5\%, 65 (1935).

[4] G. B. Kistiakowsky, J. R. Ruhoff, H. A. Smith, and W. E. Vaughan, J. Am. Chem. Soc. 5\%, 876 (1935); 58, 137 (1936).

[5] F. D. Rossini, Chem. Rev. 18, 233 (1936).

[6] F. D. Rossini, BS J. Research, 61 (1931) RP259.

[7] H. C. Dickinson and E. F. Mueller, Bul. BS 9, 483 (1913) S200.

[8] T. S. Sligh, Bul. BS 17, 49 (1922) S407.

[9] E. F. Mueller, forthcoming publication in J. Research NBS.

[10] M. Eppley, Rev. Sci. Instr. 3, 687 (1932).

[11] M. Shepherd, BS J. Research 12, 185 (1934) RP643.

[12] G. P. Baxter, O. Hönigschmid, and P. Le Beau, J. Am. Chem. Soc. 59, 219 (1937).

[13] M. Shepherd, to be described in a forthcoming publication in J. Research NBS.

[14] F. D. Rossini, J. Research NBS 15, 357 (1935) RP833.

[15] E. F. Mueller and H. F. Stimson, J. Research NBS 13, 699 (1934) RP739.

[16] P. L. Dulong, Compt. rend. 7, 871 (1838). 
[17] Grassi, J. pharm. chim. 8, 170 (1845).

[18] P. A. Favre and J. T. Silbermann, Ann. chim. phys. [3] 34, 357 (1852).

[19] T. Andrews, Phil. Mag. [3] 32, 321 (1848).

[20] M. Berthelot, Ann. chim. phys. [5] 23, 176 (1881).

[21] M. Berthelot and C. Matignon, Ann. chim. phys. [6] 30, 547 (1893).

[22] J. Thomsen, Thermochemische Untersuchungen, II and IV (Barth, Leipzig, 1882, 1886).

[23] W. G. Mixter, Am. J. Sci. 12, 347 (1901).

[24] F. D. Rossini, J. Research NBS 17, 629 (1936) RP933.

[25] Int. Critical Tables V, 163. (McGraw-Hill Book Co., New York, N. Y., 1929.)

[26] L. S. Kassel, J. Chem. Physics 4, 435 (1936).

[27] L. S. Kassel, Private communication.

Washington, June 17, 1937. 